\title{
AULA DE LEITURA: POR UMA ARTICULAÇÃO DO ESTUDO DE GÊNERO DE TEXTO COM A ANÁLISE LINGUÍSTICA
}

\author{
Paula Francineti Ribeiro de Araújo* \\ Adair Vieira Gonçalves **
}

\begin{abstract}
Resumo: Como desenvolver aula de leitura produtiva em sala de aula? É uma pergunta que objetiva apresentar um dispositivo didático aos professores em formação inicial e continuada, para turmas do Ensino Fundamental ou Médio, com base no modelo comunicativo-interativo de leitura e no modelo didático do gênero textual. A primeira etapa sugerida para as aulas de leitura consiste em orientar e ativar os conhecimentos partilhados pelos alunos para facilitar a leitura (CICUREL, 1991; LEURQUIN, 2001; 2014); na segunda etapa, recomenda-se um trabalho sistemático com as dimensões ensináveis referentes ao conjunto de observáveis, e ao contexto de produção, conjunto de parâmetros que exerce uma influência sobre a forma como o texto se organiza e aos níveis do folhado textual. (BRONCKART 2007; ADAM, 2008; DOLZ, GAGNON E DECÂNDIO, 2010).
\end{abstract}

Palavras-chave: Leitura comunicativo-interativa. Gênero de texto. Modelo Didático.

Abstract: How to develop a productive reading lesson in the classroom? It is a question which aims at presenting a didactic device to teachers in initial and continual training to groups of elementary or high school, based on the communicative-interactive model of reading and on the didactic model of the textual genre. The first step suggested for reading classes is to guide and to activate the knowledge shared by students for easier reading (Cicurel, 1991; Leurquin, 2001; 2014); on the second stepone recommends a systematic work with teachable dimensions referred to the set of observables, , and to the context of production, set of parameters that exerts an influence on the way the text is organized and to the levels of the textual leafing : (BRONCKART, 2007; ADAM, 2008; DOLZ, GAGNON and DECÂNDIO, 2010).

Keywords: Communicative-interactive reading. Text genre. Didactic model

\section{Introdução}

Em nossas recentes pesquisas, observamos que as aulas ministradas, tanto por professores de escolas públicas quanto as ministradas por professores em formação inicial durante o estágio supervisionado (ARAÚJO, 2009, 2013), comprovam que o ensino-aprendizagem da leitura e da escrita continua sendo uma tarefa tediosa de ser realizada, ao desconsiderar a linguagem em seu funcionamento nas práticas sociais, em sua realização concreta, por meio de gêneros orais e escritos e em sua multimodalidade. Os motivos para o fracasso do ensino da leitura vão, dentre tantos, desde a desarticulação entre o trabalho recomendado pelos Parâmetros Curriculares Nacionais PCN (BRASIL, 1998) a formação acadêmica, a realidade de sala aula que os levam a se sentirem despreparados como também às más condições de trabalho que lhes são oferecidas: salas de aulas lotadas, ausência de materiais e de acesso aos recursos tecnológicos etc.

Por crermos que o sentido do texto estabelece-se apenas na interação texto/leitor/autor, nossa proposta situa-se no campo dos estudos aplicados da linguagem, utilizando aportes teórico-metodológicos do interacionismo sociodiscursivo (ISD) e da concepção sociointeracionista, ambas fundamentadas, entre outras epistemologias, nos trabalhos de Vigotski (1993), especificamente no que tange à zona de desenvolvimento proximal (ZPD), estágio em que o indivíduo sozinho ainda não tem

\footnotetext{
* Docente do Instituto Técnico Federal de São Luís. Pós-Doutora em Linguística Aplicada (UFGD/MS) paulafrancineti@uol.com.br

** Docente da Universidade Federal da Grande Dourados. Doutor em Linguística e Língua Portuguesa pela Unesp Araraquara.. adairgoncalves@ uol.com.br
} 
autonomia para resolver os problemas, e, por essa razão, necessita da contribuição de outrem. Vale ressaltar que a ZPD está estritamente relacionado à experiência profissional do professor; torna-se, portanto, imprescindível que os profissionais de Letras dominem saberes fundadores da área que ensinam. Conforme as orientações dos PCN (BRASIL, 1998), o ensino de leitura deve levar o aluno a dominar as situações diversas de comunicação, como utilizar os diferentes gêneros de textos que circulam socialmente, a fim de que se torne realmente um cidadão ativo em uma sociedade letrada. Uma formação insuficiente determinará, na maioria dos casos, uma prática de ensino improdutiva, longe do alcance dos objetivos desejados. Neste contexto, surge a questão: como desenvolver leitura produtiva em sala de aula?

A título de contribuição, este trabalho tem o objetivo de sugerir uma proposta de aula de leitura comunicativo-interativa direcionada tanto para turmas do Ensino Fundamental quanto para o Ensino Médio. Sua divisão deverá ficar a critério do professor, consoante à carga-horária destinada para o ensino de Língua Portuguesa e o da leitura mais especificamente.

Para este fim, elegemos o gênero de texto reportagem intitulado $O$ terrivel mundo dos comentários da internet ${ }^{1}$, publicada na seção Comportamento da revista Superinteressante (SUPER/ out. 2014, p. 56-61), que pertence tradicionalmente à esfera jornalística e/ou da divulgação científica por abordar em suas reportagens temas diversos que relatam as peripécias da atualidade e da história como também do mundo social, como o Cyberbullying ${ }^{2}$, uma nova modalidade de bullying que ocorre no mundo real, mas que, devido às inovações tecnológicas surgidas no início do século XXI e à popularização da Internet 2.0 (web participativa) ${ }^{3}$, passou a ser praticada no mundo virtual.

Este artigo, com ênfase no objeto de ensino de leitura, está dividido, além das considerações iniciais e finais, em três seções. Na subseção Sobre os modelos de leitura e seus impactos em sala de aula, abordaremos as diferentes concepções que permearam (ou ainda permeiam) o ensino de leitura em sala de aula. Na subseção Sobre a leitura comunicativo-interativa (CICUREL 1991; LEURQUIN, 2014), apresentaremos a primeira etapa da proposta de leitura que consiste em orientar e ativar os conhecimentos partilhados pelos alunos para a facilitação da leitura. Na subseção Sobre o modelo didático do gênero textual, apresentaremos a segunda etapa de leitura consoante às dimensões ensináveis concernentes às propriedades do gênero de texto reportagem com base no conjunto de observáveis e/ou da leitura do texto em busca de informações de ordem semântica, léxico-sintática e paralinguística (BRONCKART, 2007), além de outros elementos envolvidos como o contexto de produção e os níveis do folhado textual: infraestrutura do texto, os mecanismos de textualização e os mecanismos enunciativos (BRONCKART, 2007; ADAM, 2008).

\footnotetext{
1 Disponível em: <http://m.gloss.com.br/cotidiano/terrivel-mundo-comentarios-internet-829521.shtml>. Acesso em: 16 abr. 2016.

${ }^{2}$ Os praticantes de ciberbullying ou "bullying virtual" utilizam os modernos recursos tecnológicos na área da informação e da comunicação (fixa e móvel): e-mails, blogs, fotoblogs, fotoshop, MSN, Skipe, Twitter, Facebook, WhatsApp, valendo-se muitas vezes do anonimato, para tecer comentários racistas, preconceituosos e sexistas de forma desrespeitosa ou para deixar mensagens ou opinar de forma inconveniente sobre determinado assunto para semear brigas, desordem e desentendimentos entre os participantes sérios e interessados, causando-lhes consequências psicológicas incalculáveis (SILVA, 2010).

${ }^{3}$ Este termo foi utilizado para descrever o conceito de serviços de WEB e novos tipos de aplicação de software que permitem aos usuários colaborar e contribuir para o processo, além de desenvolver, avaliar, comentar ou distribuir conteúdos digitais na internet.
} 


\section{2 . Sobre os modelos de leitura e seus impactos em aula de leitura}

Os PCN de Língua Portuguesa (BRASIL, 1998) conceituam a leitura como

[...] o processo no qual o leitor realiza um trabalho ativo de compreensão e interpretação do texto, a partir de seus objetivos, de seu conhecimento sobre o assunto, sobre o autor, de tudo o que sabe sobre a linguagem etc. Não se trata de extrair informação, decodificando letra por letra, palavra por palavra. Trata-se de uma atividade que implica estratégias de seleção, antecipação, inferência e verificação, sem as quais não é possível proficiência. É o uso desses procedimentos que possibilita controlar o que vai sendo lido, permitindo tomar decisões diante de dificuldades de compreensão, avançar na busca de esclarecimentos, validar no texto suposições feitas (MEC/SEF, 1998, p. 69-70).

No entanto, o ensino de leitura em algumas salas de aula está atrelado ainda a diferentes modelos tradicionais que as sustentam, legitimam e perpetuam. Tais modelos são resenhados resumidamente a seguir:

O modelo linguístico, mecanicista ou tradicional (foco no autor) vê a linguagem como um sistema fechado, autônomo, constituído de componentes não relacionados entre si, só existindo no objeto, no material escrito, que deve ser assimilado pelo leitor no ato de ler (LEURQUIN, 2001). Nessa perspectiva, de um lado, o professor nega-se a admitir que o leitor verbalize seu ponto de vista; de outro, o autor é tomado como modelo a ser seguido para falar e escrever bem. A leitura deve ser cuidadosa e o dicionário deve ser consultado sempre que necessário. Para Leurquin (2001), a leitura restringe as possibilidades de o aluno interagir com o texto, a partir do momento em que apenas o decodifica, sem questionar e estabelecer relações inter e extratextuais. A aprendizagem nesse processo, desprovida de funcionalidade, torna-se repetitiva, mecânica. A técnica de ler se sobressai à compreensão e ao significado; o trabalho do professor é pautado por frases feitas, textos fragmentados, descontextualizados com o objetivo apenas de ensinar regras gramaticais.

O modelo estruturalista de leitura (foco no texto), segundo Gonçalves e Barros (2011), tem suas bases na visão de língua como estrutura, já que esta é vista como ato de decodificação dos sentidos dos signos linguísticos presentes no texto. Na acepção de Koch e Elias (2006, p.10, grifos das autoras), tal modelo corresponde a um sujeito determinado, "assujeitado" pelo sistema, caracterizado por uma espécie de "não consciência". A leitura nessa concepção "é uma atividade que exige do leitor o foco no texto, em sua linearidade, uma vez que "tudo está dito no dito" (KOCH; ELIAS, 2006, p.10, grifos das autoras).

O modelo psicolinguístico de leitura (foco no leitor), com base na teoria cognitiva, desloca-se na direção do sujeito (o leitor) e de sua atividade mental; não mais incide sobre o objeto (o texto). Influenciado por Chomsky (1970), tal modelo defende a existência de um falante/ouvinte ideal, de comunidade homogênea de fala, desconsiderando a diversidade da língua. A linguagem é concebida como um objeto desprovido de suas funções sociais, desvinculado de elementos socioculturais, de seu contexto de produção e de sua atualização em comunidades heterogêneas de fala (LEURQUIN, 2001).

No modelo interacionista (foco na interação autor-texto-leitor), de acordo com Koch e Elias (2006), a leitura "é uma atividade complexa de produção de sentidos, que 
se realiza com base nos elementos linguísticos presentes na superfície textual e na sua forma de organização, mas requer a mobilização de um vasto conjunto de saberes no interior do evento comunicativo". Para Hoppe e Costa-Hübes (2016), ao fazer uso da linguagem, o indivíduo age sobre o seu interlocutor (ouvinte/leitor), resultando numa produção de sentidos entre locutores, que ocupam posições sociais, históricas, culturais e ideológicas.

O modelo sociolinguístico (foco no evento) compreende a leitura como uma atividade pessoal, social, cultural e histórica. Neste modelo, o leitor constrói um texto durante a leitura num evento que não se concretiza apenas no contexto de sua realização, já que são levadas em conta também as interações dos participantes. Porém, quando a leitura é uma atividade de sala de aula apenas para testar conhecimentos, esse desencontro de objetivos pode afetar a compreensão do aluno, ressalta Leurquin (2001).

Nossa concepção de leitura apoia-se no modelo comunicativo-interativo que deriva desses dois últimos modelos supracitados. O modelo comunicativo-interativo (foco em um novo evento) ancora-se no modelo interacionista, cujo foco é a interação leitor-texto-autor e no modelo sociopsicolinguístico, cujo foco é o evento. Nessa perspectiva, de acordo com Leurquin (2014), o professor desempenha o papel de tutor que colabora para que a compreensão ocorra de forma coletiva na sala de aula. Do ponto-de-vista da Didática, em certa medida, as concepções de ensino apresentadas por este modelo estão em consonância com os PCN (BRASIL, 1998), pois requer, segundo Gonçalves, Barros e Napoilitano (2011), que o aluno conheça as especificidades (contextuais, discursivas e linguísticas) dos diferentes gêneros textuais. Conforme os autores,

[...] o conhecimento interacional refere-se aos meios de interação linguageiro, e estão relacionados aos propósitos comunicativos, quantidade de informação necessária numa dada situação de interação, seleção da variante linguística, adequação ao gênero textual, utilização de configurações textuais específicas (conhecimentos paralinguísticos) e conhecimentos do gênero e tipos textuais) (GONÇALVES; BARROS, 2011, p. 283),

As aulas de leitura, nessa perspectiva, ultrapassam a mera decodificação e o foco apenas na estrutura ou na intenção do autor. $O$ ato de leitura torna-se, assim, um processo no qual interagem leitor-texto-autor em um determinado evento.

\subsection{Sobre a leitura comunicativo-interativa}

A proposta de leitura comunicativo-interativa (CICUREL, 1991), redefinida por Leurquin (2014), é constituída de quatro etapas ${ }^{4}$, pautadas não somente nos objetivos da aula de leitura, como também no contexto comunicacional, no texto selecionado, na situação de produção e em outros elementos envolvidos no evento. Em nossa proposta, aglutinamos a primeira e a segunda etapas por considerarmos que ambas objetivam os

\footnotetext{
${ }^{4}$ Na versão original (CICUREL 1991 apud LEURQUIN, 2001), a primeira etapa consiste em orientar e ativar os conhecimentos prévios para facilitar a leitura, compreendendo a utilização de três técnicas: o acionamento dos conhecimentos; o cenário de antecipação e a associação de ideias a partir de palavraschave; a segunda etapa caracteriza-se pela observação e antecipação, na qual o professor faz com que o aluno se familiarize com o texto; a terceira etapa remete ao ato de ler com um objetivo, na qual o professor pode selecionar uma ou várias entradas no texto; por fim, a última etapa vai tratar do tempo que temos para reagir e refazer as ligações do conhecimento.
} 
conhecimentos adquiridos pelos leitores sobre o tema tratado no texto. A primeira etapa da aula consiste em orientar e ativar os conhecimentos partilhados pelos alunos para a facilitação da leitura. Neste momento, o aluno ainda não leu o texto. Portanto, sua importância, de acordo com Leurquin, justifica-se pelo fato de possibilitar-lhe a formulação de hipóteses que serão confirmadas ou não na sequência da aula. Esta etapa compreende a utilização de três fases, a saber:

a) $\quad O$ acionamento dos conhecimentos partilhados: tem como objetivo acionar os conhecimentos sobre bullying/cyberbullying em torno das seguintes questões: o que significa bullying/cyberbullying? Quem já sofreu (ou sofre) algum tipo de bullying/cyberbullying? Em caso positivo, quem gostaria de relatar para os seus colegas sua experiência? Quais foram os efeitos e/ou consequências do bullying/cyberbullying em sua vida? Como lidou com isso? Etc.

b) O cenário de antecipação: é consequência da primeira fase, objetivando o acionamento dos cenários (comentários sobre post de Facebook ou de notícia e artigo de opinião contidos em blogs) armazenados na memória do leitor, de forma que possa estabelecer relações, associações, usando sua memória episódica.

c) A associação de ideias a partir de palavras-chave: objetiva proporcionar uma situação em que o leitor possa utilizar palavras-chave que permitam associações (boas maneiras, intolerância, decoro, integridade, honradez etc.)

\subsection{Sobre o modelo didático do gênero reportagem}

Nesta subseção, apresentamos a segunda etapa de nossa proposta de aula de leitura que remete ao ato de ler com um objetivo. Nesta etapa, podemos selecionar uma ou várias entradas no texto. Para cumpri-la, fizemos reconcepções do modelo didático ${ }^{5}$ proposto por Dolz, Gagnon e Decândio (2010), a fim de explicitar as dimensões ensináveis referentes ao conjunto de observáveis, propriedades de ordem semântica, léxico-sintática e paralinguística do gênero; ao contexto de produção, conjunto de parâmetros que exerce uma influência sobre a forma como o texto se organiza e aos níveis do folhado textual: gestão dos tipos de discurso que compõem o texto e condicionam sua infraestrutura, dos mecanismos de textualização e dos mecanismos enunciativos (BRONCKART, 2007).

\subsection{A entrada pelo gênero de texto}

Neste artigo, sugerimos o ensino de língua portuguesa pelas atividades de leitura articuladas às atividades de inferência e codificação das regularidades observáveis e de funcionamento do gênero de texto reportagem e dos tipos de discurso associados ao contexto de produção: escolha do gênero: modalidades de organização do conteúdo temático (plano do texto); às regras que presidem a sinalização dessa planificação (condições de emprego dos organizadores textuais); às modalidades de gerenciamento das séries isotópicas que contribuem para a coerência textual (condições

\footnotetext{
${ }^{5}$ Em sua origem, o modelo didático foi elaborado e conceitualizado como uma ferramenta para se organizar o ensino de produção textual por meio dos gêneros. Trata-se da "[...] descrição provisória das principais características de um gênero textual com o objetivo de ensiná-las. É uma construção em engenharia didática que explicita as seguintes dimensões: os saberes de referência a serem mobilizados para se trabalhar os gêneros; a descrição dos diferentes componentes textuais específicos; as capacidades de linguagem do aluno" (DOLZ; GAGNON; DECÂNDIO, 2010, p. 48).
} 
de empregos dos pronomes, dos tempos verbais etc.); às modalidades de distribuição das vozes e dos posicionamentos do enunciador.

Nesta entrada, portanto, damos início à exploração, de ordem comunicativa e pragmática, das características do gênero de texto reportagem, que contribuem para diferenciá-lo de outros gêneros, como também para refletir sobre os elementos linguísticos que o compõe e lhe dão sentido.

A reportagem é um gênero de texto da ordem do relatar ${ }^{6}$ cujo objetivo é abordar um tema a partir da perspectiva do repórter ou jornal/revista, que objetiva atingir os interesses de seus destinatários. De acordo com Bueno, neste gênero procura-se tratar de um assunto observando as suas raízes e desdobramentos, ou seja, ocorre neste gênero, "um tratamento mais aprofundado dos fatos do que nas notícias. Ao seu elaborador, cabe a investigação, a pesquisa, a fim de construir um texto mais completo" (BUENO, 2011, p.94). A pesquisa é, por conseguinte, central na reportagem. Para escrever, é necessário que o produtor consulte livros, resultados de pesquisas sobre o assunto e especialistas, entreviste pessoas etc. Dessa forma, a reportagem faz uma apresentação mais panorâmica e em maior profundidade das informações. Entre as características da reportagem, podemos citar: (i) causas e efeitos do fato ocorrido; (ii) detalhamento do fato; (iii) soma de versões; (iv) engendramento de informações; (v) indícios claros de personalização; (vi) narrativa, com inquérito e entrevista; (vii) fixação de uma notícia: criando raízes e ganhos desta; (viii) retrato a partir de ângulo pessoal. (FARIA; ZANCHETA Jr., 2002)

$\mathrm{Na}$ imprensa brasileira, podemos encontrar, conforme Bahia (1990 apud Bueno, 2001), os seguintes esquemas de reportagem:

1) Pirâmide invertida: reportagem em que o repórter apresenta as informações em ordem decrescente de importância;

2) Pirâmide normal: reportagem do tipo cronológica, semelhante à narrativa literária convencional. O texto inicia mostrando fatos importantes, depois faz-se a narração das ações chegando a um clímax;

3) Modelo misto: mistura dos dois modelos anteriores. No início do texto, apresenta-se o ponto mais dramático e, no restante, desenvolvem-se os elementos essenciais que levem o leitor a uma ampliação do clímax da história. No interior deste tipo, é bem comum a apresentação de depoimentos, entrevistas, informações secundárias etc.

De acordo com Faria e Zancheta Jr. (2002), na reportagem, os personagens envolvidos podem ser apresentados de diversas formas:

- Apresentação explícita: o repórter traça determinado retrato da personagem.

- Apresentação implícita: o personagem mostra-se por suas palavras e ações.

- Apresentação do indivíduo: o interesse recai sobre atitudes do entrevistado.

\footnotetext{
${ }^{6}$ A reportagem corresponde "ao domínio social de comunicação da documentação e memorização de ações humanas ligadas à capacidade de linguagem do relatar - representação pelo discurso de experiências vividas, situadas no tempo" (DOLZ; NOVERRAZ; SCHNEUWLY, 2004, p. 121).
} 
- Apresentação do tipo: predomínio da característica que dá fama ao personagem.

- Apresentação caricatural: exagero de traços da personagem, deformando-os.

\subsection{A entrada pelo conjunto de observáveis}

Nesta entrada, abordamos o conjunto de observáveis, com o objetivo de descrever as propriedades, variedades e estrutura do gênero de texto reportagem.

Com relação às propriedades observáveis de ordem semântica, em nosso exemplo de reportagem, o tipo de discurso predominante é o relato-interativo/teórico, com passagens do discurso interativo, materializado por sequências narrativas, explicativas, argumentativas, explicitadas adiante. Neste caso, o discurso interativo também se faz presente como estratégia utilizada pelo redator para aproximar-se propositadamente dos mais jovens, público-alvo dessa revista.

Em relação às propriedades observáveis da ordem léxico-sintática, os fatos são marcados pelo pretérito perfeito e pretérito imperfeito, às vezes, associados às formas verbais do pretérito mais-que-perfeito, do futuro do presente e do pretérito; pela presença de organizadores temporais e espaciais e ostensivos, caracterizando o discurso relato interativo; podendo ocorrer também verbos no presente para marcar ora a fala do entrevistado e/ou do redator, marcas linguísticas do discurso interativo; ora a definição/explicação, típicas do discurso teórico. Em se tratando das propriedades observáveis de ordem paralinguística, na reportagem $O$ terrível mundo dos comentários na internet, a configuração composicional apresenta um título, seguido de um lead, sobre o que o texto vai tratar, como segue:

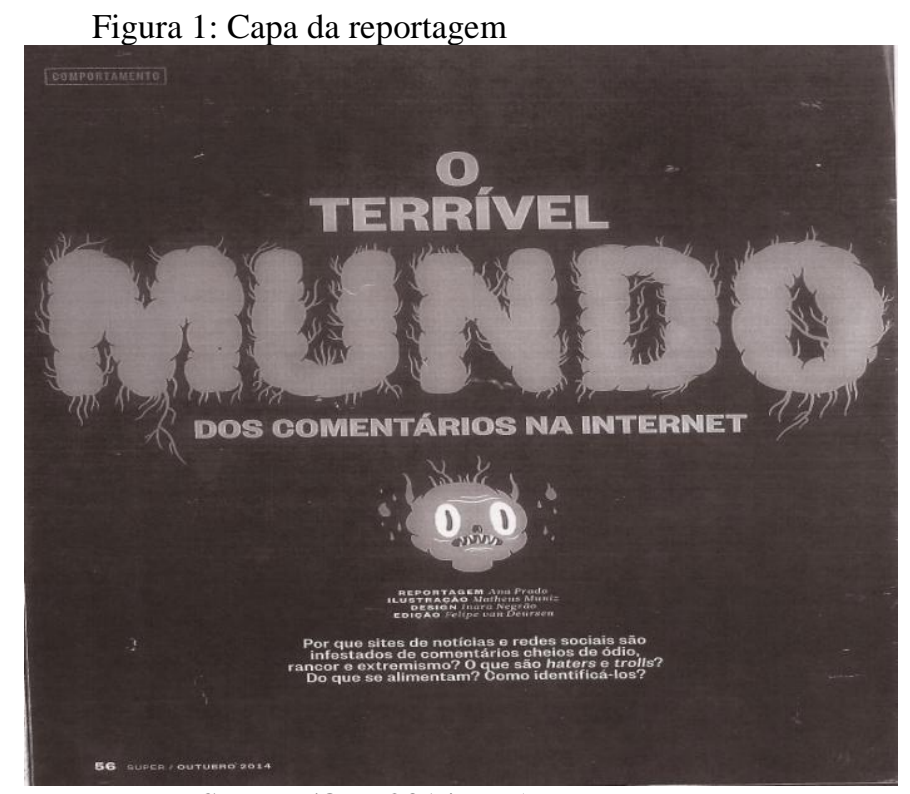

Fonte: SUPER/Out. 2014, p. 56.

O corpo do texto é dividido em 13 parágrafos, distribuídos em duas colunas. $\mathrm{O}$ primeiro é introduzido por um tipo (letra A) com uma configuração maior que os 
demais caracteres, marcado com aspas que inicia uma citação; os demais parágrafos são entremeados por subtítulos que introduzem o assunto que vão tratar.

Figura 2: Corpo do texto

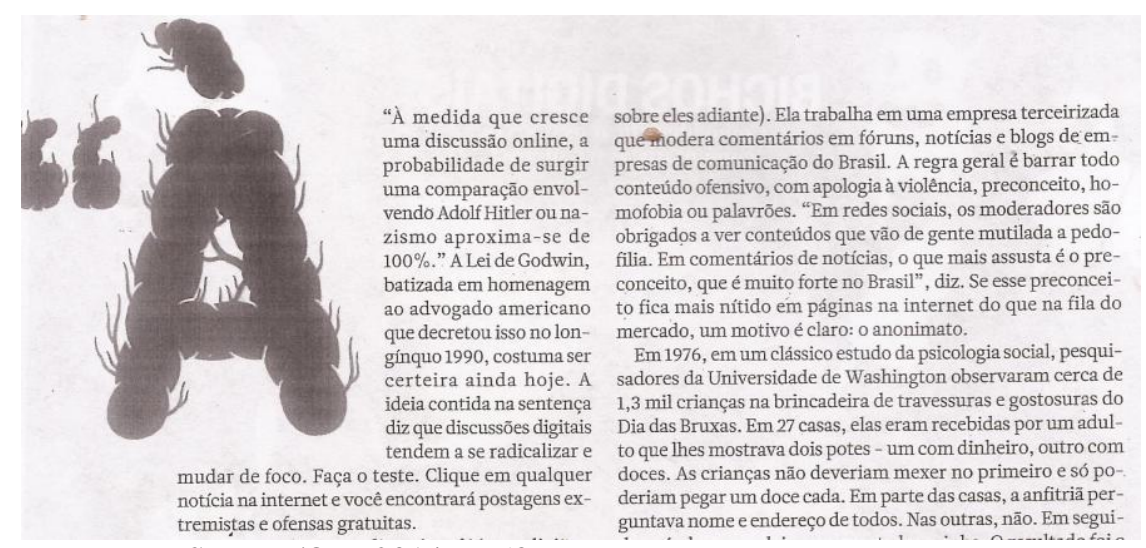

Fonte: SUPER/Out. 2014, p. 58.

O texto também apresenta figuras e um infográfico que conceitua e descreve os tipos de comentaristas na internet.

Figura 3: Corpo do texto: infográfico

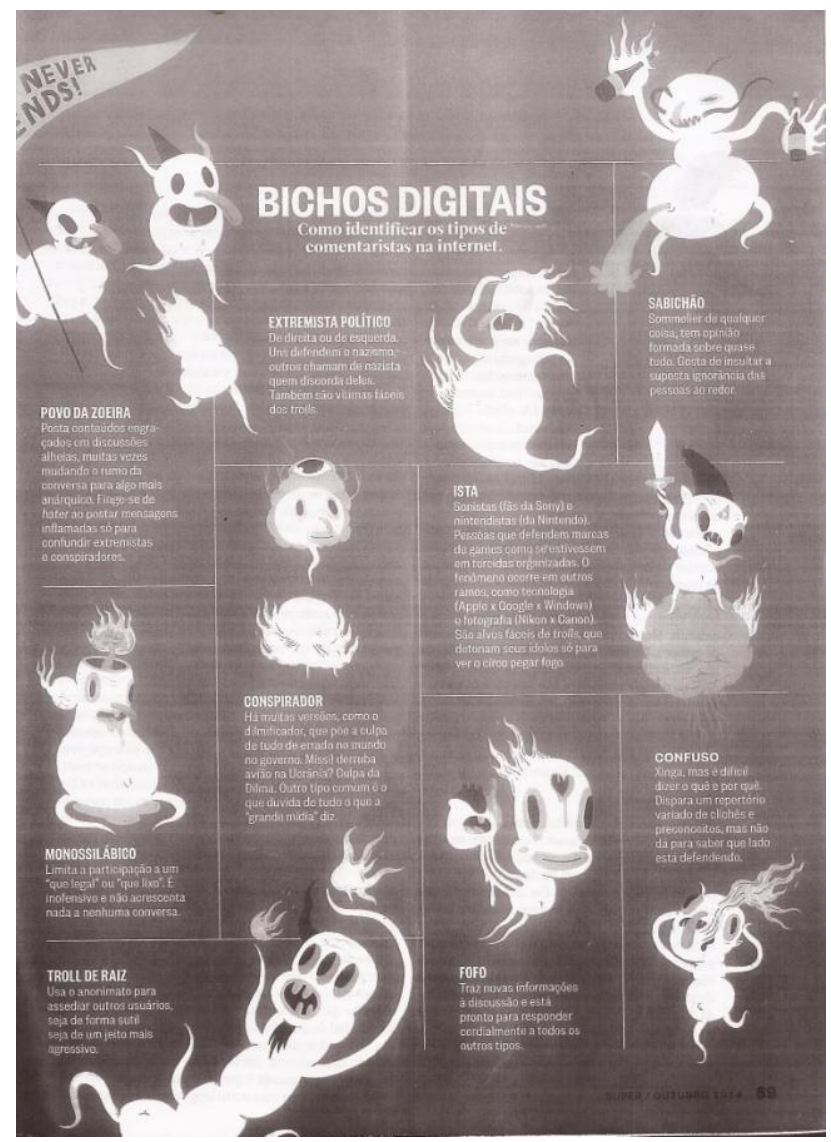

Fonte: SUPER/Out. 2014, p. 59. 


\subsection{A entrada pelo contexto de produção}

Nesta entrada, abordamos o contexto de produção, que pode ser definido como um conjunto de parâmetros que exerce influência sobre a forma como um texto se organiza (BRONCKART, 2007). Esses parâmetros podem ser agrupados em dois conjuntos: físico e sócio-subjetivo.

O contexto físico é decomposto em quatro parâmetros. Em se tratando desta reportagem, temos:

Quadro 1: contexto físico

\begin{tabular}{l|l}
\hline $\begin{array}{l}\text { lugar de produção: o lugar físico em que o } \\
\text { texto é produzido. }\end{array}$ & Editora Abril \\
\hline $\begin{array}{l}\text { momento de produção: extensão do tempo } \\
\text { durante o qual o texto é produzido. }\end{array}$ & Mensal \\
\hline $\begin{array}{l}\text { emissor (produtor): a pessoa que produz } \\
\text { fisicamente o texto. }\end{array}$ & $\begin{array}{l}\text { Ana Prado (redação), Matheus Muniz } \\
\text { (ilustração), Inara Negrão (design) Felipe van } \\
\text { Deursen (edição) }\end{array}$ \\
\hline $\begin{array}{l}\text { receptor: a(s) pessoa(s) que pode(m) perceber } \\
\text { (ou receber) concretamente o texto. }\end{array}$ & Leitores da Superinteressante \\
\hline
\end{tabular}

O contexto sócio-subjetivo também pode ser decomposto em quatro parâmetros

Quadro 2: contexto sócio-subjetivo

\begin{tabular}{l|l}
\hline $\begin{array}{l}\text { lugar social: no quadro de qual formação } \\
\text { social? }\end{array}$ & Esfera jornalística \\
\hline $\begin{array}{l}\text { posição social do emissor: do enunciador, } \\
\text { aquele que transmite alguma coisa para } \\
\text { alguém. }\end{array}$ & $\begin{array}{l}\text { Ana Prado (jornalista), Matheus Muniz } \\
\text { (ilustrador), Inara Negrão (designer) Felipe } \\
\text { van Deursen (editor) }\end{array}$ \\
\hline posição do receptor, do destinatário. & Jovens da faixa etária entre 14 a 35 anos \\
\hline objetivo: a intenção da comunicação. & Informar
\end{tabular}

\subsection{A entrada pelo folhado textual}

Nesta entrada, abordamos os níveis do folhado textual, constituído de três camadas superpostas: a infraestrutura do texto, os mecanismos de textualização e os mecanismos enunciativos.

\subsubsection{A infraestrutura do texto}

A infraestrutura do texto é constituída pelo plano geral do texto, ou seja, pelos tipos de discurso que comporta, pelas modalidades de articulação entre esses tipos de discurso e pelas sequências que nele aparecem. O plano geral refere-se à organização de conjunto do conteúdo temático, que pode ser observado no processo de leitura e codificado por meio de um resumo de suas partes constitutivas. O nosso texto-exemplo apresenta-se da seguinte forma:

a) Trata das postagens extremistas e ofensivas na internet. $\$ 1$

b) Relata e comenta fatos sobre esses tipos de postagens na internet. $\$ 2$

c) Relata o depoimento sobre essas postagens de uma entrevistada. §3 
d) Relata um estudo psicológico sobre o anonimato do indivíduo na internet. $\$ 4$

e) Apresenta vários exemplos de situações cotidianas de anonimatos. §5

f) Compara essas situações cotidianas de anonimatos com as da internet. $\S 6 \mathrm{e}$ 7

g) Relata de estudos sobre o comportamento dos indivíduos na internet. $\S 8,9$, 10

h) Define e relata o comportamento dos trolls. $\S 11,12$

i) Conclui retomando os aspectos principais. $\S 13$

\subsubsection{Os tipos de discurso}

Os tipos de discurso ${ }^{7}$ são os elementos essenciais da infraestrutura geral dos textos. São segmentos de texto que apresentam características linguísticas específicas identificáveis nos textos, articulados entre si por mecanismos de textualização e por mecanismos enunciativos que conferem ao todo textual sua coerência sequencial e configuracional. No caso, do texto-exemplo, podemos identificar uma fusão desses tipos, constituindo um verdadeiro tipo misto relato-interativo-interativo-teórico.

$\mathrm{O}$ discurso relato interativo caracteriza-se pela ausência de frases não declarativas e pela presença dos tempos verbais no pretérito perfeito e imperfeito, às vezes, associados às formas verbais do mais-que-perfeito, futuro do presente e pretérito e pela presença de organizadores temporais e espaciais.

Quadro 3: discurso relato interativo

\begin{tabular}{|c|c|}
\hline $\begin{array}{l}\text { SEGMENTOS DO DISCURSO RELATO } \\
\text { INTERATIVO }\end{array}$ & $\begin{array}{l}\text { ANÁLISE DO DISCURSO } \\
\text { INTERATIVO DO TEXTO }\end{array}$ \\
\hline $\begin{array}{l}\text { Os psicólogos Justin Hepler e Dolores } \\
\text { Albarracín, das universidades americanas de } \\
\text { Illinois e da Pensilvânia, respectivamente, } \\
\text { publicaram um estudo em } 2013 \text { que ajuda a } \\
\text { explicar o ódio online. } \$ 8\end{array}$ & $\begin{array}{l}\text { Ausência de frases não declarativas } \\
\text { (imperativas, exclamativas, interrogativas) }\end{array}$ \\
\hline $\begin{array}{l}\text { Durante um mês, mergulhei nesse lodaçal de } \\
\text { comentários. } \\
\text { [...] Seu avô já dizia que discutir política, } \\
\text { religião e futebol podia dar encrenca. [...] §2 }\end{array}$ & $\begin{array}{l}\text { Presença dos tempos verbais no pretérito } \\
\text { perfeito e imperfeito, às vezes, associados às } \\
\text { formas verbais mais-que-perfeito, futuro do } \\
\text { presente e pretérito. }\end{array}$ \\
\hline $\begin{array}{l}\text { Algumas vezes, um repórter famoso do canal } \\
\text { interagia [...] Quando o repórter comentava } \\
{[\ldots] \S 10}\end{array}$ & Presença de anáforas nominais por repetição. \\
\hline $\begin{array}{l}\text { Só que tem um problema: existem pessoas e } \\
\text { pessoas. E algumas delas são trolls. }\end{array}$ & Presença de sintagmas pronominais \\
\hline $\begin{array}{l}{[\ldots] \text { No começo do ano, algumas mulheres }} \\
\text { criaram páginas no Facebook contra o assédio } \\
\text { sexual. [...] Em junho, em uma notícia } \\
\text { publicada no portal Exame.com sobre os } \\
\text { países com menores índices de violência, um } \\
\text { usuário escreveu: }[\ldots . .] \S 2\end{array}$ & $\begin{array}{l}\text { Presença de organizadores temporais e } \\
\text { espaciais }\end{array}$ \\
\hline
\end{tabular}

${ }^{7} \mathrm{O}$ modelo da arquitetura textual utilizado para análise propõe quatro tipos de discurso: discurso interativo, discurso teórico, relato interativo e narração (BRONCKART, 2007, p. 166-177). 
O discurso interativo (tipo secundário no texto-exemplo), caracteriza-se pela presença do presente do indicativo, indicando o momento da fala; pelos turnos de fala, pela presença de numerosas frases não declarativas; pela presença de unidades dêiticas espaciais, dêiticas temporais e ostensivos ${ }^{8}$ e de anáforas pronominais.

Quadro 4: discurso interativo

\begin{tabular}{|c|c|}
\hline $\begin{array}{lll}\text { SEGMENTOS } & \text { DO } & \text { DISCURSO } \\
\text { INTERATIVO } & & \end{array}$ & ANÁLISES \\
\hline $\begin{array}{l}\text { Faça o teste. Clique em qualquer notícia na } \\
\text { internet e você encontrará postagens } \\
\text { extremistas e ofensas gratuitas. } \S 1\end{array}$ & Presença de frases imperativas \\
\hline $\begin{array}{l}\text { Lembra seus primeiros posts no Orkut, em } \\
\text { blogs antigos ou logo que entrou no } \\
\text { Facebook? } 13\end{array}$ & Presença de frases interrogativas. \\
\hline $\begin{array}{l}\text { Você não pode chutá-los porque estão dentro } \\
\text { das regras, mas muita gente se revolta e perde } \\
\text { a linha. } \$ 11\end{array}$ & $\begin{array}{l}\text { Presença de pronome de primeira e segunda } \\
\text { pessoa do singular e plural }\end{array}$ \\
\hline $\begin{array}{l}{[\ldots] \text { "Estou acostumado. Sei que esse pessoal }} \\
\text { está aí para fazer bullying. Mas quem não } \\
\text { está preparado pode ter a vida transformada } \\
\text { em um inferno" [...] } 6 \\
{[\ldots] \text { "Os reacionários são minorias, mas são os }} \\
\text { mais barulhentos. Acho que muita gente que } \\
\text { concorda comigo não comenta. Em blogs que } \\
\text { defendem ideias de direita, quem é de } \\
\text { esquerda é que pega mais pesado". [...] §6 }\end{array}$ & $\begin{array}{l}\text { Presença do presente do indicativo, indicando } \\
\text { o momento da fala. }\end{array}$ \\
\hline $\begin{array}{l}\text { Sei que esse pessoal está aí para fazer } \\
\text { bullying. } \$ 6\end{array}$ & Presença de unidades dêiticas espaciais \\
\hline No começo do ano... § 2 & Presença de unidades dêiticas temporais \\
\hline $\begin{array}{l}\text { Então imagine como é trabalhar todo dia com } \\
\text { isso. } \S 2\end{array}$ & 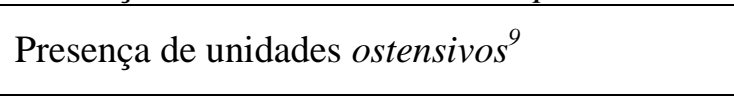 \\
\hline $\begin{array}{l}\text { A moderação desse conteúdo conta com } \\
\text { algoritmos que fazem uma filtragem prévia, } \\
\text { [...], que ainda precisa de pessoas. Elas são } \\
\text { [...]. § } 3\end{array}$ & Anáforas pronominais \\
\hline
\end{tabular}

O discurso teórico caracteriza-se pela ausência de frases não declarativas (exclamativas, interrogativas e imperativas), composto de dois tempos verbais dominantes: o presente e/ou pretérito perfeito de valor genérico, no qual os interlocutores da comunicação não são apresentados concretamente.

Quadro 5: discurso teórico

\begin{tabular}{l|l}
\hline SEGMENTOS DO DISCURSO TEÓRICO & ANÁLISE \\
\hline $\begin{array}{l}\text { Os trolls apareceram na rede de fóruns Usenet } \\
\text { nos anos 80. §11 }\end{array}$ & $\begin{array}{l}\text { Ausência de frases não declarativas } \\
\text { (imperativas, } \\
\text { interrogativas) }\end{array}$ \\
\hline $\begin{array}{l}\text { Há muito lixo na internet. § 1 } \\
\text { [... É } \text { a função dos moderadores, que limpamativas, }\end{array}$ & $\begin{array}{l}\text { Presença de verbos no presente do } \\
\text { indicativo, indicando uma validade geral, }\end{array}$ \\
\hline
\end{tabular}

8 Unidades que remetem a objetos acessíveis aos interactantes (BRONCKART, 2007, p. 169). 
diariamente blogs e sites do chorume da internet, a fim de remover frases ofensivas. $E$ um trabalho enorme. [...] $\S 2$

$\mathrm{O}$ resultado dividiu as pessoas em dois grupos: [...] $O$ primeiro grupos [...]. $\mathrm{O}$ segundo [...]. Isso cria um padrão de comportamento em que o que é avaliado é menos importante do que quem avalia. § 8

A medida que cresce uma discussão online, a probabilidade de surgir uma comparação envolvendo Adolf Hitler ou nazismo aproxima-se de 100\%". A Lei de Godwin, batizada em homenagem ao advogado americano que decretou isso no longínquo 1990, costuma ser certeira ainda hoje. [...]§ 1 independente de qualquer temporalidade particular.

Como acabamos de mostrar, as articulações entre tipos de discurso podem tomar diferentes formas. O texto-exemplo é constituído predominantemente por formas linguísticas (morfossintáticas e semânticas) que caracterizam o discurso relatointerativo, no interior do qual foram encaixados segmentos de discurso interativo e de discurso teórico que serviram para marcar ou tornar mais visível a estruturação de seu conteúdo temático.

\subsection{3 - As sequências textuais ${ }^{10}$}

As sequências são modos de organização da linguagem em partes, no interior de um texto, constituídas por unidades de sentido, conectadas entre elas por um mesmo modo de organização de texto: narrativa, descritiva, explicativa, argumentativa, dialogal, etc. Nesta reportagem, podemos identificar as seguintes sequências:

A sequência narrativa ${ }^{11}$ aparece nos relatos interativos (contexto real) e nas narrações (contexto ficcional). No caso do texto-exemplo que relata fatos ocorridos, caracteriza-se pela presença dos elementos como segue:

[S. Narr.] Em 1976, em um clássico estudo da psicologia social, pesquisadores da Universidade de Washington observaram cerca de 1, 3 mil crianças na brincadeira de travessuras e gostosuras do Dia das Bruxas. Em 27 casas, elas eram recebidas por um adulto que lhes mostrava dois potes - um com dinheiro, outro com doces. As crianças não deveriam mexer no primeiro e só poderiam pegar um doce de cada. Em parte das casas, a anfitriã perguntava nome e endereço de todos. Nas outras, não. Em seguida, saía de cena e deixava a garotada sozinha. A conclusão todo moleque que já quebrou vidraça do vizinho sabe. Grupos de anônimos são mais propensos a desrespeitar regras, pois acreditam que sairão impunes. $\S 4$

Quadro 6: sequência narrativa

\footnotetext{
${ }^{10}$ As sequências textuais são marcadas assim: [S. Narr.] para sequência narrativa; [S. Descr.], sequência descritiva; [S. Expl.], sequência explicativa; [S. Arg.], sequência argumentativa. As letras entre colchetes marcam as partes da sequência.

${ }^{11}$ As sequências narrativas só aparecem nos relatos interativos e nas narrações. No contexto ficcional, o enunciador conta uma história fictícia (romance, conto, crônica, novela, etc. É estruturada em cinco elementos principais: narrador, personagens, enredo ou trama, tempo/espaço e apresenta as seguintes fases: apresentação, complicação, clímax, desfecho ou desenlace, resolução, situação final (BRONCKART, 2007, p. 220-221).
} 


\begin{tabular}{|c|c|}
\hline SEGMENTOS DE SEQUÊNCIA NARRATIVA & ANÁLISE \\
\hline Em 1976, [...] & Quando? (tempo em que o fato ocorreu) \\
\hline em um clássico estudo da psicologia social & O quê (o fato) \\
\hline [...] da Universidade de Washington & Onde? (o lugar onde o fato se deu) \\
\hline $\begin{array}{l}\text { [...] pesquisadores da Universidade de Washington } \\
\text { observaram cerca de } 1,3 \text { mil crianças na } \\
\text { brincadeira de travessuras e gostosuras do Dia das } \\
\text { Bruxas. }\end{array}$ & Com quem? (quem observou ou participou do fato) \\
\hline $\begin{array}{l}\text { [...] Em } 27 \text { casas, elas eram recebidas por um } \\
\text { adulto que lhes mostrava dois potes - um com } \\
\text { dinheiro, outro com doces. }\end{array}$ & Por quê? (o motivo que determinou o fato) \\
\hline $\begin{array}{l}\text { [...] As crianças não deveriam mexer no primeiro } \\
\text { e só poderia pegar um doce cada. Em seguida, saía } \\
\text { de cena e deixava a garotada sozinha. O resultado } \\
\text { foi o esperado: houve mais trapaça entre crianças } \\
\text { em grupo, especialmente quando elas eram } \\
\text { anônimas. Quando davam nome e endereço, } 20 \% \\
\text { trapaceavam. Quando não diziam nada, } 60 \% \\
\text { enchiam os bolsos de doces e, às vezes, até } \\
\text { moedas. }\end{array}$ & $\begin{array}{l}\text { Como? (o modo como deu ou deram-se o (s) } \\
\text { fato(s) }\end{array}$ \\
\hline $\begin{array}{l}\text { A conclusão todo moleque que já quebrou vidraça } \\
\text { do vizinho sabe. Grupos de anônimos são mais } \\
\text { propensos a desrespeitar regras, pois acreditam que } \\
\text { sairão impunes. }\end{array}$ & Desfecho (as consequências provocadas pelo fato) \\
\hline
\end{tabular}

A sequência explicativa ocorre quando o enunciador visa resolver um problema, isto é, facilitar para o destinatário a compreensão de um objeto do discurso considerado problemático (de difícil compreensão).

Quadro 7: sequência explicativa

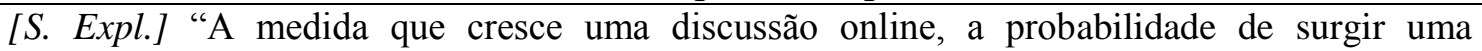
comparação envolvendo Adolf Hitler ou nazismo aproxima-se de 100\%. A lei de Godwin, batizada em homenagem ao advogado que decretou isso no longínquo 1990, costuma ser certeira ainda hoje. A ideia contida na sentença diz que discussões digitais tendem a se radicalizar e mudar de foco. $\$ \mathbf{1}$

\begin{tabular}{l|l}
\hline SEGMENTOS DE SEQUÊNCIA & ANÁLISE \\
EXPLICATIVA & \\
\hline $\begin{array}{l}\text { A medida que cresce uma discussão online, a } \\
\text { probabilidade de surgir uma comparação } \\
\text { envolvendo Adolf Hitler ou nazismo } \\
\text { aproxima-se de 100\%. }\end{array}$ & O sujeito da explicação \\
\hline $\begin{array}{l}\text { A lei de Godwin, batizada em homenagem ao } \\
\text { advogado que decretou isso no longínquo } \\
1990, \text { costuma ser certeira ainda hoje. [...] }\end{array}$ & A justificativa da necessidade da explicação \\
\hline $\begin{array}{l}\text { A ideia contida na sentença diz que discussões } \\
\text { digitais tendem a se radicalizar e mudar de } \\
\text { foco. }\end{array}$ & A explicação do fenômeno \\
\hline
\end{tabular}

A sequência argumentativa aparece quando o enunciador pretende convencer, por meio da utilização de argumentos, um aspecto do tema (exposição ou defesa de ideias), que (a seu ver e/ou do destinatário) pode ser contestável. 
Quadro 8: sequência argumentativa

[S. Arg.] Essa desindividualização é comum. Parado no trânsito, você já se pegou fazendo coro a outros motoristas dizendo coisas horríveis ao fulano lá na frente que travou um cruzamento? E xingar a mãe do juiz no estádio? Somos um só nessa bagunça, não há um indivíduo definido. Não nos sentimos responsáveis. § 5

\begin{tabular}{l|l}
\hline SEGMENTOS DE SEQUÊNCIA & ANÁLISE \\
ARGUMENTATIVA & Premissa \\
\hline Essa desindividualização é comum & \\
\hline $\begin{array}{l}\text { Parado no trânsito, vocês já se pegou fazendo } \\
\text { coro a outros motorista dizendo coisas } \\
\text { horríveis ao fulano lá na frente que travou um } \\
\text { cruzamento? E xingar a mãe do juiz no } \\
\text { estádio? }\end{array}$ & Argumentos \\
\hline $\begin{array}{l}\text { Somos um só nessa bagunça, não há indivíduo } \\
\text { definido. }\end{array}$ & Contra-argumento \\
\hline Não nos sentimos responsáveis. & Conclusão \\
\hline
\end{tabular}

A heterogeneidade do texto-exemplo é constituída pela combinação e articulação de diferentes tipos de sequências (narrativas, explicativas e argumentativas), de caráter fundamentalmente dialógico, previamente organizado na memória da agente-produtora (no caso, a jornalista), motivado pelas representações que o enunciador tem das propriedades dos seus destinatários (jovens da faixa etária entre 14 e 35 anos), assim como do efeito que neles deseja produzir.

\subsection{A entrada pelo mecanismo de textualização}

Nesta entrada, abordamos os mecanismos de textualização que contribuem para o estabelecimento da coerência temática e podem ser reagrupados em três grandes conjuntos: conexão, coesão nominal e coesão verbal.

Os mecanismos de conexão servem para marcar as grandes articulações da progressão temática realizadas por meio de organizadores textuais que marcam as transições entre tipos de discurso, entre fases de uma sequência textual ${ }^{12}$ ou ainda entre frases sintáticas. Os mecanismos, portanto, explicitam as relações existentes entre os diferentes níveis de organização de um texto, assumindo as seguintes funções:

- No nível mais englobante, exercem a função de segmentação: delimitam as partes constitutivas do texto e assinalam os diferentes tipos de discurso que

\footnotetext{
${ }^{12}$ No estudo desta reportagem, nos concentramos na análise das sequências textuais de Adam adotada por Bronckart, que substitui a noção de macroproposição pela noção de fase ou seja, a forma prototípica padrão de um dado segmento de texto. O protótipo-padrão de uma sequência narrativa, por exemplo, é composta por uma ordem de sucessão obrigatória: situação inicial, complicação, ações, resolução, situação final, podendo ser acrescentada mais duas, dependendo do posicionamento do narrador: avaliação e moral; o protótipo-padrão de uma sequência descritiva é composta das seguintes partes: ancoragem, aspectualização e relacionamento; da sequência argumentativa: premissas, argumentos, contra-argumentos, conclusão (ou nova tese); da sequência explicativa: constatação inicial, problematização, resolução, conclusão-avaliação; a sequência dialogal: abertura, transacional, encerramento (BRONCKART, 2007).
} 
correspondem a essas partes por meio de unidades linguísticas diversas como advérbios e locuções adverbiais: (no começo, em junho, etc.), sendo que a maioria não desempenha função sintática na frase em que aparece, mas algumas podem assumir a função de adjunto adverbial (Durante um mês, mergulhei...); Conjunções de coordenação (mas, etc.)

- No nível inferior, exercem a função de demarcação ou balizamento: marcam os pontos de articulação entre as fases de uma sequência extual ou de uma outra forma de planificação, por meio das mesmas unidades linguísticas que marcam a segmentação.

- No nível mais inferior, exercem a função de empacotamento: explicitam as modalidades de integração das frases sintáticas à estrutura que constitui a fase de uma sequência textual ou de uma outra forma de planificação, por meio de conjunções de coordenação (mas, etc.)

- E por extensão, esses mesmos mecanismos exercem a função de ligação (justaposição, coordenação) ou de encaixamento (subordinação), que articulam duas ou várias frases sintáticas em uma só frase gráfica.

O quadro a seguir agrupa algumas desses mecanismos de conexão manifestados no texto-exemplo.

Quadro 9: tipos de conexões

\begin{tabular}{|c|c|}
\hline CONEXÕES & SEGMENTOS \\
\hline $\begin{array}{l}\text { SEGMENTAÇÃO (DISCURSO } \\
\text { INTERATIVO/DISCURSO TEÓRICO) }\end{array}$ & $\begin{array}{l}\text { Seu avô já dizia que discutir política, religião e } \\
\text { futebol podia dar encrenca. Se esses embates } \\
\text { podem ocorrer no bar com amigos, na terra de } \\
\text { anônimos da internet a coisa baixa a selvageria. \$2 }\end{array}$ \\
\hline $\begin{array}{l}\text { SEGMENTAÇÃO (DISCURSO RELATO- } \\
\text { INTERATIVO/DISCURSO TEÓRICO) }\end{array}$ & $\begin{array}{l}\text { No começo, algumas mulheres criaram páginas no } \\
\text { Facebook [...]. E a violência não se limita a } \\
\text { questões de gênero, é claro. \$2 }\end{array}$ \\
\hline $\begin{array}{l}\text { SEGMENTAÇÃO (DISCURSO RELATO- } \\
\text { INTERATIVO/DISCURSO INTERATIVO) }\end{array}$ & $\begin{array}{l}\text { Em junho, em uma notícia publicada no portal } \\
\text { Exame.com [...] um usuário escreveu: “[...] Não } \\
\text { estou cometendo racismo, apenas citando um } \\
\text { fato." \$2 }\end{array}$ \\
\hline BALIZAMENTO & $\begin{array}{l}\text { "Não ofende ninguém, mas é campeão da } \\
\text { discórdia." §11 }\end{array}$ \\
\hline $\begin{array}{l}\text { EMPACOTAMENTO (DE FRASES EM UMA } \\
\text { MESMA FASE DA ARGUMENTAÇÃO) }\end{array}$ & $\begin{array}{l}\text { A moderação desse conteúdo conta com } \\
\text { algoritmos que fazem uma filtragem prévia, mas } \\
\text { isso é parte do trabalho, que ainda precisa de } \\
\text { pessoas. \$2 } \\
\text { A internet é isso, só que pior, porque há corpo } \\
\text { presente e a turba é incrivelmente maior. § 6 }\end{array}$ \\
\hline ENCAIXAMENTO & $\begin{array}{l}{[\ldots] \text { Uma causa séria e delicada. Menos para os }} \\
\text { homens que as ameaçaram de estupro [...] \$2 }\end{array}$ \\
\hline LIGAÇÃO & $\begin{array}{l}\text { Clique em qualquer notícia na internet e você } \\
\text { encontrará postagens extremistas e ofensas } \\
\text { gratuitas. \$1 }\end{array}$ \\
\hline
\end{tabular}

\section{- Coesão nominal}

A coesão nominal é feita por sintagmas nominais ou pronominais organizados em cadeias anafóricas. As anáforas nominais são compostas por pronomes pessoais, relativos, demonstrativos e possessivos e também por alguns sintagmas nominais de diversos tipos (podem ser idênticos a seu antecedente (Em comentários de notícias, o 
que mais assusta é o preconceito [...]. Se esse preconceito fica [...] § 3) ou podem se diferenciar no plano lexical (As crianças não deveriam mexer no primeiro [...] Em seguida, saía de cena e deixava a garotada sozinha $\$ 4)$ ) ou no plano das marcas de determinação (Algumas vezes, um repórter famoso do canal interagia [...] Quando o repórter comentava [...] § 10), ou ainda nos dois planos (Só no Facebook, [...] compartilham links e opiniões por mês § 2). A moderação desse conteúdo conta com [...] § 2). As anáforas pronominais são compostas de pronomes pessoais, relativos, possessivos demonstrativos e reflexivos. Duas funções de coesão nominal podem ser distinguidas:

Introdução: marca, em um texto, a inserção de uma unidade de significação nova (ou unidade fonte) que é a origem de uma cadeia anafórica (pronominal ou nominal).

Retomada: consiste em reformular a unidade-fonte (ou antecedente) no decorrer do texto, como segue:

Quadro 10: coesão nominal

\begin{tabular}{l|l}
\hline FUNÇÕES DE COESÃO NOMINAL & SEGMENTOS \\
\hline UNIDADE FONTE (ANTECEDENTE) & $\begin{array}{l}{[\ldots] \text { é parte do trabalho, que precisa de }} \\
\text { pessoas. §2 }\end{array}$ \\
\hline & $\begin{array}{l}\text { Elas são, em grande parte, estudantes da [...] } \\
\text { que }(\tilde{\boldsymbol{g}}) \text { ganham cerca de... §2 } \\
\text { Bruna é uma delas. O nome é fictício porque } \\
\text { seu trabalho a torna alvo de [...]. Ela trabalha } \\
\text { em uma empresa [...]. }\end{array}$ \\
\hline
\end{tabular}

- Coesão verbal

A coesão verbal assegura a organização temporal e/ou hierárquica dos processos (as espécies de relações expressas pela semântica do verbo: os estados, os acontecimentos e as ações), verbalizados no texto e realizada, principalmente pelos tempos verbais que aparecem em interação com outras unidades possuidoras de valor temporal (advérbios e organizadores textuais, principalmente) cuja distribuição depende, mais do que os mecanismos de conexão e coesão nominal, dos diferentes tipos de discurso em que aparecem, conforme analisado anteriormente.

No texto-exemplo, os mecanismos de textualização (séries isotópicas de organizadores e de retomadas nominais) contribuíram para marcar ou tornar mais visível a estruturação do conteúdo temático (plano geral que combina tipos de discursos e sequências) como também sua infraestrutura (organização mais profunda).

\subsection{Entrada pelos mecanismos enunciativos}

Nesta entrada, abordamos os mecanismos enunciativos que contribuem para a manutenção da coerência pragmática (ou interativa) do texto: as vozes e modalizações. Os mecanismos enunciativos contribuem para o estabelecimento dos posicionamentos enunciativos (Quais são as instâncias que assumem o que é enunciado no texto? Quais são as vozes que nele se expressam?) e traduzem as diversas avaliações (julgamentos, opiniões, sentimentos) sobre alguns aspectos do conteúdo temático, com o objetivo de orientar a interpretação do texto pelo leitor. 


\section{- As vozes enunciativas}

À primeira vista, é o autor (ou agente-produtor) que assume ou se posiciona em relação ao que é enunciado, a partir da posição sócio-subjetiva que ele assume na interação verbal em curso. Pode acontecer de o texto mobilizar vozes "outras" que podem ser reagrupadas em três categorias gerais:

A voz do autor empírico do texto - é a voz que precede diretamente da pessoa que está na origem da produção textual e intervém para comentar ou avaliar aspectos do que é enunciado. As vozes de instâncias sociais - são vozes procedentes de personagens, grupos ou instituições sociais que não intervêm como agentes no percurso temático de um segmento de texto, mas são mencionados como instâncias externas de avaliação de alguns aspectos desse conteúdo. As vozes de personagens - são vozes procedentes de seres humanos ou de entidades humanizadas. Pode tratar-se de heróis em cena no relato ou na narração, ou dos interlocutores implicados num discurso interativo dialogado, ou ainda do "criador de conhecimentos", às vezes, posto em cena em um discurso teórico (BRONCKART, 2003).

Quadro 11: vozes enunciativas

\begin{tabular}{l}
\hline SEGMENTOS \\
"É muito difícil para algumas pessoas aceitar o fato \\
de que além de ser bonita e inteligente, a raça branca \\
$e$ é a mais evoluída. Não estou cometendo racismo, \\
apenas citando um fato." $\S 1$ \\
\hline "Em redes sociais, os moderadores são obrigados a \\
ver conteúdos que vão de gente mutilada a pedofilia. \\
Em comentários de notícias, o que mais assusta é o \\
preconceito, que é muito forte no Brasil." $\S 3$
\end{tabular}

"Estou acostumado. Sei que esse pessoal está aí para fazer bullying. Mas quem não está preparado pode ter a vida transformada em um inferno." $\$ 6$

ANALISES DAS VOZES

Voz de um personagem, procedente de uma instância social (grupos racistas) que crer na supremacia de uma raça em detrimento de outras.

Voz do autor empírico na tomada consciência do alto grau de preconceito da população brasileira. Voz de um personagem (blogueiro), manifestada pelo autor empírico, que tem que se manter imune às críticas negativas postadas pelos usuários quando não estão de acordo com a sua opinião.

Voz do autor empírico, na tomada de

"A ideia nunca foi criar algo polêmico. Mas não sabia que direitos humanos era um tema tão espinhoso no Brasil.” $§ 6$ consciência que ao tratar de temas relacionados aos direitos humanos iria causar tantos descontentamentos aos leitores do seu blog.

"Faça o teste. Clique em qualquer notícia na internet e você encontrará postagens extremistas e ofensas gratuitas." $\$ 1$

Voz de um personagem (que poderia ser uma pessoa do seu convívio) manifestada pelo autor empírico, com o objetivo de diminuir a distância entre ele e seu leitor.

\section{- As modalizações}

As modalizações pertencem à dimensão configuracional do texto, contribuindo para o estabelecimento de sua coerência pragmática ou interativa, orientando o leitor na interpretação de seu conteúdo temático. Elas podem ser efetuadas de diferentes maneiras e reagrupadas como segue: 
Modalizações lógicas (ou epistêmicas): consistem em julgamentos sobre o valor de verdade das proposições enunciadas que são apresentadas como certas, possíveis, prováveis, eventuais, improváveis etc. (certamente, provavelmente, sem dúvida, é verdade que, etc.).

Modalizações deônticas: avaliam o que é enunciado à luz dos valores sociais, apresentando os fatos enunciados como (socialmente) permitidos, proibidos, necessários, desejáveis, etc. São realizadas por unidades ou conjunto de unidades linguísticas do tipo (é permitido, é desejável, é preciso, é evidente que..., é possível que..., etc.)

Modalizações apreciativas: traduzem um julgamento mais subjetivo, apresentando os fatos enunciados como bons, maus, estranhos, na visão da instância que avalia. São realizadas por unidades ou conjunto de unidades linguísticas do tipo (é estranho, é pena, felizmente, etc.);

Modalizações pragmáticas: introduzem um julgamento sobre uma das facetas da responsabilidade de um personagem em relação ao processo de que é agente, principalmente sobre a capacidade de ação (o poder-fazer), a intenção (o querer-fazer) e as razões (o dever-fazer). São realizadas por unidades ou conjunto de unidades linguísticas do tipo (poderia fazer, teria querido fazer, ser preciso, dever etc.) (BRONCKART, 2003).

Quadro 12: modalizações

\begin{tabular}{|c|c|}
\hline SEGMENTOS & ANÁLISES DAS MODALIZAÇÕES \\
\hline $\begin{array}{l}\text { "E a violência não se limita a questões de } \\
\text { gênero, é claro." } § 2\end{array}$ & $\begin{array}{l}\text { Lógica, para afirmar que o comportamento das } \\
\text { pessoas na internet independe do sexo. }\end{array}$ \\
\hline $\begin{array}{l}\text { "Se esse preconceito fica mais nítido em } \\
\text { páginas na internet do que na fila do mercado, } \\
\text { um motivo é claro: o anonimato." } \$ 4\end{array}$ & $\begin{array}{l}\text { Lógica, para considerar como certa sua opinião } \\
\text { de que as transgressões das regras na internet é } \\
\text { por conta da situação de anonimato em que as } \\
\text { pessoas se encontram. }\end{array}$ \\
\hline “[...] e a turba é incrivelmente maior.” $§ 6$ & $\begin{array}{l}\text { Apreciativa, para traduzir a sua constatação de } \\
\text { que o comportamento das pessoas na internet é } \\
\text { bem pior do que em outros ambientes. }\end{array}$ \\
\hline $\begin{array}{l}\text { "As crianças não deveriam mexer no primeiro } \\
\text { e só poderiam pegar um doce cada" } § 4\end{array}$ & $\begin{array}{l}\text { Pragmática, para julgar o comportamento das } \\
\text { crianças com relação à capacidade de ação (o } \\
\text { poder-fazer). }\end{array}$ \\
\hline $\begin{array}{l}\text { "Lembra seus primeiros posts no Orkut, em } \\
\text { blogs antigos ou logo que entrou no } \\
\text { Facebook? Bateu uma vergonha? É normal." } \\
\S 13\end{array}$ & $\begin{array}{l}\text { Deôntica, para avaliar o fato enunciado como } \\
\text { socialmente permitido. }\end{array}$ \\
\hline
\end{tabular}

No texto-exemplo, os mecanismos enunciativos (vozes e modalizações) contribuem para marcar a interação entre a agente-produtora e seus destinatários.

A última etapa da aula trata do tempo oferecido para o aluno reagir e refazer as ligações dos conhecimentos. Neste momento, os alunos confrontam as hipóteses levantadas na primeira etapa com as informações contidas no texto a fim de validá-las. Para este momento, concluímos com as seguintes perguntas: Você já transgrediu alguma regra por estar acompanhado de um grupo de colegas? Se sim, o que você fez? 
Onde? Como? Por quê? Sua atitude trouxe quais consequências? Você repetiria o que fez? Você costuma chamar a atenção de alguém por ter transgredido uma regra?

Antes da leitura do texto, discutimos alguns valores que são comumente transgredidos pelas pessoas, principalmente, no ambiente virtual (falta de boas maneiras, intolerância, decoro, integridade, honradez, etc.). Qual desses valores são infringidos pelos bichos digitais? Com qual dos bichos digitais você se identifica? Caso você não se identifique com nenhum, qual deles faz você lembrar de alguém e/ou de algum caso?

\section{Para concluir}

O trabalho de leitura com o texto aqui proposto visa um enfoque diretamente prático em uma lógica descendente centrado nos três níveis de sua organização interna.

Com relação ao nível infraestrutura do texto, a organização geral comporta as vertentes conteúdo e expressão da produção linguageira consideradas do ponto de vista de suas formas gerais de organização: a do planejamento geral do conteúdo temático (temas e conhecimentos mobilizados).

Com relação ao nível intermediário, os mecanismos de textualização que confere ao texto sua coerência temática contribuíram para marcar as unidades e estruturas mobilizadas no texto à proporção que progredia. Identificamos diferentes tipos de discurso (segmentos que relatam os acontecimentos, segmentos que expressam o ponto de vista do enunciador, segmentos em que o enunciador se dirige ao destinatário) e sequências (narrativas, explicativas e argumentativas) que funcionam no nível de segmentos de texto. Tais segmentos, como vimos, podem ser analisados e descritos linguisticamente, já que mobilizam um subconjunto de unidades linguísticas específicas (certas formas verbais, certos pronomes, certos organizadores etc.).

Quanto aos mecanismos de conexão, estes foram marcados por articulações da progressão temática concernente ao plano geral do texto quanto à passagem de um tipo de discurso a outro ou de uma sequência a outra, realizados através de organizadores textuais (conjunções, advérbios, grupos nominais), funcionando como operadores lógico-argumentativos, temporais ou metatextuais; Com relação aos mecanismos de coesão textual, eles tiveram duas funções complementares: de introduzir unidades de informações novas e de assegurar a retomada dessas unidades na sequência do texto, realizadas por séries isotópicas e por unidades anafóricas (nomes ou grupos nominais e pronomes).

Com relação ao nível superficial, os mecanismos de posicionamento enunciativo e de modalização, contribuíram para dar ao texto sua coerência pragmática e interativa. Identificamos uma forte presença da voz do autor empírico do texto assumindo a responsabilidade do que estava sendo dito e a partir dela identificamos outras vozes: de personagens e instâncias sociais. Quanto às modalizações que avaliam o conteúdo temático e emanam dessas vozes realizam-se por advérbios e por certos tempos verbais.

As proposições teóricas aqui utilizadas, que serviram como instrumento de análise, demonstraram ser possível visualizarmos uma didática para o ensino de leitura articulada à análise linguística. Porém, vale ressaltar, que o ensino de qualquer gênero de texto exige que o professor domine não só os aportes teóricos referentes ao gênero em questão como também seu conteúdo temático para que possa então definir quais dimensões ensináveis poderão ser objetos de seu projeto de ensino em prol do desenvolvimento das capacidades de linguagem de seus alunos. 


\section{REFERÊNCIAS}

ADAM, J-M. A linguística textual: introdução à análise textual dos discursos. São Paulo: Cortez, 2008.

ARAUJO, P.F. O gerenciamento das vozes enunciativas no gênero fatia de vida da ordem do relatar. Dissertação em Linguística. Departamento de Letras Vernáculas, UFC, Fortaleza, 2009.

ARAUJO, P.F. Cenas do estágio curricular supervisionado: descrição, interpretação e análise discursivo-enunciativas de práticas dos professores em formação. Tese de Doutorado em Linguística. Departamento de Letras Vernáculas, UFC, Fortaleza, 2013.

BRASIL. Parâmetros curriculares nacionais: terceiro e quarto ciclos do ensino fundamental. Brasília: MEC/Secretaria de Educação Fundamental, 1998.

BRONCKART, J.P. Atividade de linguagem, textos e discursos: por um interacionismo sociodiscursivo. São Paulo: Educ, 2007.

CHARTRAND, S-G.; AUBIN, D.; RAYMOND, B.; SIMARD, C. Grammaire pédagogique du français d'aujourd'hui. Montréal: GRAFICOR, 1999.

CHOMSKY, N. La langage et la pensée. Paris: Payot, 1970.

CICUREL, F. Lecture interatives en langue étrangère. Paris, Hachette, 1991.

DOLZ, J.; GAGNON, R.; DECÂNDIO, F. Produção escrita e dificuldades de aprendizagem. São Paulo. Mercado de Letras, 2010.

DOLZ, J.; SCHNEUWLY, B. Gêneros orais e escritos na escola. São Paulo: Mercado de letras, 2004.

FARIA, M. A.; ZANCHETA. J. Para ler e fazer o jornal em sala de aula. São Paulo: Contexto, 2002.

GONÇALVES, A. V. ; BARROS, E. e NAPOILITANO, A. A. Dificuldades de compreensão de textos em situação de vestibular. Acta Scientiarum. Langage and $\begin{array}{llllll}\text { Culture, } & \text { v. } & 33, & \mathrm{n}^{\mathrm{o}} \quad 2, & \text { pp. } & 281-292,\end{array}$ http://periodicos.uem.br/ojs/index.php/ActaSciLangCult/article/view/12181

HOPPE, M. C.; COSTA-HÜBES, C. T. da. Concepções de leitura na educação básica e a sua relação com a prova Brasil. Em aberto. Local, p. 1-15. Disponível em www.histedbr.fe.unicamp.br/acer_histedbr/jornada/jornada11/artigos/7/artigo-simposio7-1036-inter-marcia@hotmail.com.pdf. Acesso em: 13.mar.2016.

KOCH, I.; ELIAS, V. Ler e compreender os sentidos do texto. São Paulo: Contexto, 2006.

LEURQUIN, E. V. L. Contrato de Comunicação e concepção de leitura na prática pedagógica de língua portuguesa. Tese de Doutorado em Educação, Programa de PósGraduação em Educação, UFRGN, Natal, 2001.

LEURQUIN, E. V. L. O espaço da leitura e da escrita em situação de ensino e de aprendizagem de português língua estrangeira. Revista Eutomia v.14, nº 1, pp. 167-186, 2014. 
LIMA, A. A. M. de. Cyberbullying e outros riscos na internet: despertando a atenção de pais e professores. Rio de Janeiro: Wak, 2011.

SILVA, A.B. Mentes perigosas nas escolas: bullying. Rio de Janeiro: Fontanair, 2011.

VYGOTSKY, L. S. Pensamento e linguagem. São Paulo: Martins Pontes, 1993.

Recebido em 31 de maio de 2018

Aceito em 23 de julho de 2018 